\title{
Effect of chloride channel activity on retinal pigment cell proliferation and migration
}

\author{
JING ZHAO $^{1,2}$, WEI ZHONG ${ }^{2}$, LIXIA SUN $^{1}$, YUAN YIN $^{1}$ and YAJUAN ZHENG ${ }^{1}$ \\ ${ }^{1}$ Department of Ophthalmology, The Second Hospital of Jilin University, Jilin University, Changchun, Jilin 130041; \\ ${ }^{2}$ Department of Ophthalmology, China-Japan Union Hospital, Jilin University, Changchun, Jilin 130031, P.R. China
}

Received December 7, 2015; Accepted December 15, 2016

DOI: $10.3892 / \mathrm{mmr} .2017 .6202$

\begin{abstract}
The present study aimed to investigate the effects of chloride channels $(\mathrm{ClC})$ on the proliferation and migration of retinal pigment epithelial (RPE) cells, a primary component of proliferative vitreoretinopathy (PVR) membranes. An RPE cell model of phagocytosis was established using fibronectin-coated latex beads. Cell proliferation was measured by live cell counting. The cell cycle and phagocytosis index was assessed by flow cytometry. Intracellular calcium concentration was quantified using Fura-2-acetoxymethyl ester. $\mathrm{ClCs}$ were blocked using 5-nitro-2-(3-phenylpropylamino) benzoic acid (NPPB) and tamoxifen (TAM). NPPB and TAM were identified to inhibit the proliferation of ARPE-19 human adult RPE cells by arresting them in the $G_{0} / G_{1}$ phase, inhibit the phagocytosis of fibronectin, and decrease intracellular calcium levels, in a dose-dependent manner. ClCs serve important roles in mediating human RPE cell proliferation and migration. The underlying mechanisms of action of $\mathrm{ClCs}$ are associated with the regulation of calcium. Targeting $\mathrm{ClCs}$ may provide a novel strategy to inhibit PVR formation.
\end{abstract}

\section{Introduction}

Proliferative vitreoretinopathy (PVR), a retinal damage repair process, is a common cause of severe visual impairment or blindness (1). Retinal pigment epithelial (RPE) cells are a primary component of PVR membranes, and abnormal RPE cell migration and proliferation contributes to PVR (2). The pathological basis for PVR is the destruction of the blood-retinal barrier, which causes the subretinal RPE cells to directly contact the vitreous. RPE cells lose their connection to the RPE extracellular matrix by an unknown underlying mechanism.

Correspondence to: Dr Yajuan Zheng, Department of Ophthalmology, The Second Hospital of Jilin University, Jilin University, 218 Ziqiang Street, Changchun, Jilin 130041, P.R. China E-mail: zhengyajuan124@126.com

Key words: retinal pigment cell, chloride channel, proliferation, proliferative vitreoretinopathy
The cells subsequently undergo epithelial-mesenchymal transition, localize to the vitreous, proliferate and organize into an epiretinal membrane. Contraction of the membrane may cause retinal detachment $(3,4)$. During PVR, components of the extracellular matrix, including fibronectin (FN), collagen and laminin, appear in the epiretinal membrane; however, the importance of this is unclear. $\mathrm{FN}$ is a glycoprotein that is crucial for promoting cell growth and adhesion, maintaining cell structure, and wound repair and healing $(5,6)$. Subretinal and epiretinal membranes exhibit high levels of FN $(7,8)$.

Chloride channels (ClCs) are widely distributed throughout mammalian organs and serve important roles in maintaining cell volume and regulating cell activity, proliferation, differentiation and division (9). ClC activity determines whether cells enter the $S$ or $\mathrm{G}_{0}$ phase (10-12). In addition, ClC-2 and -3 are involved in morphological alterations, which are closely associated with cell migration and invasion. Numerous $\mathrm{ClCs}$ have been cloned, including $\mathrm{ClC}-1$ to $-7, \mathrm{ClC}-\mathrm{ka}$ and $\mathrm{ClC}-\mathrm{kb}$. It has been demonstrated that $\mathrm{ClCs}$ are expressed in RPE cells $(13,14)$. $\mathrm{ClC}$ blockers include 5-nitro-2-(3-phenylpropylamino) benzoic acid (NPPB) and tamoxifen (TAM), which may prevent the proliferation and migration of glioma cells (15-17). Little is known about the association between $\mathrm{ClCs}$, the proliferation and migration of RPE cells, and PVR.

ARPE-19 is a well-established adult human RPE cell line that has been widely used as a model for in vitro RPE cell research $(18,19)$. The present study cultured ARPE-19 cells with $\mathrm{ClC}$ blockers in vitro to investigate the effects of $\mathrm{ClCs}$ on the proliferation and cell cycle of human RPE cells. Additionally, the present study established an RPE cell model of phagocytosis, using FN-coated latex beads, to examine the effect of $\mathrm{ClCs}$ on RPE cell migration. These results may provide a basis for novel studies aimed at the prevention and treatment of PVR.

\section{Materials and methods}

RPE cell culture. The ARPE-19 human adult RPE cell line (American Type Culture Collection, Manassas, VA, USA) was cultured in Dulbecco's modified Eagle's medium/Nutrient Mixture F-12 (DMEM/F-12; Gibco; Thermo Fisher Scientific, Inc., Waltham, MA, USA) supplemented with $10 \%$ fetal bovine serum, $100 \mathrm{U} / \mathrm{ml}$ penicillin and $100 \mathrm{mg} / \mathrm{ml}$ streptomycin (Sigma-Aldrich; Merck Millipore, Darmstadt, Germany). The 
cells were maintained in a humidified incubator at $37^{\circ} \mathrm{C}$ and $5 \% \mathrm{CO}_{2}$.

Dose-dependence of RPE cell viability. NPPB and TAM (Sigma-Aldrich; Merck Millipore) stock solutions were prepared in dimethyl sulfoxide and serially diluted with serum-free DMEM/F12 medium. ARPE-19 cells were cultured in the medium, in the presence or absence of 10 , 50 or $100 \mu \mathrm{M}$ NPPB or 5,10 or $50 \mu \mathrm{M}$ TAM, for $48 \mathrm{~h}$ and subsequently suspended in phosphate-buffered saline (PBS) with $0.1 \%$ trypan blue dye (Sigma-Aldrich; Merck Millipore) for $10 \mathrm{~min}$. Staining was measured by flow cytometry (Coulter EPICS $^{\circledR}$ XL $^{\text {TM }}$; Beckman Coulter, Inc., Brea, CA, USA) and cell viability was calculated under an inverted light microscope (CH20-BIM; Olympus Corporation, Tokyo, Japan).

Cell proliferation assay. ARPE-19 cells were seeded into 24 Petri dishes at a density of $4 \times 10^{4}$ cells $/ \mathrm{ml}$, and incubated for $48 \mathrm{~h}$ with NPPB or TAM as described in the previous section. The cells were digested with $0.25 \%$ parenzyme (Gibco; Thermo Fisher Scientific, Inc.). Trypan blue (1\%) was added to $0.9 \mathrm{ml}$ of each cell suspension. Cells were counted by a blinded observer using a hemocytometer. Mean values were calculated from three replicates for each group.

Cell cycle determination. ARPE-19 cells were seeded into six Petri dishes at a density of $4 \times 10^{4}$ cells $/ \mathrm{ml}$ in media containing $100 \mu \mathrm{M}$ NPPB or $50 \mu \mathrm{M}$ TAM. After $48 \mathrm{~h}$, the cells were digested with $0.25 \%$ parenzyme, washed three times with PBS, and resuspended in $0.5 \mathrm{ml}$ PBS. Triton X-100 (0.15\%) and RNase (5 mg/ml; Sigma-Aldrich; Merck Millipore) were added to each suspension. Following incubation for $10 \mathrm{~min}$ at room temperature, DNA was stained with $25 \mu \mathrm{g} / \mathrm{ml}$ propidium iodide (Santa Cruz Biotechnology, Inc., Dallas, TX, USA) for $10 \mathrm{~min}$ at room temperature. The stained cells were filtered through a nylon filter membrane (Sigma-Aldrich; Merck Millipore) and DNA was quantified by flow cytometry at an excitation wavelength of $488 \mathrm{~nm}$. MULTICYCLE ${ }^{\circledR}$ software version 5.0 (Beckman Coulter, Inc.) was used to analyze the cell cycle in 10,000 cells per sample.

Establishment of a model for RPE cell phagocytosis. ARPE-19 cells were cultured for $24 \mathrm{~h}$ in 6 Petri dishes at a density of $2.5 \times 10^{5}$ cells $/ \mathrm{ml}$, to a confluence of $70-95 \%$. Fluorescent-labeled latex beads (emission wavelength, $515 \mathrm{~nm}$; diameter, $1.0 \mu \mathrm{m}$; Thermo Fisher Scientific, Inc.) were diluted in PBS to a density of $5 \times 10^{7}$ latex beads $/ \mathrm{ml}$ and mixed with FN (Sigma-Aldrich; Merck Millipore) to a final concentration of $1.0 \mu \mathrm{g} / \mathrm{ml} \mathrm{FN}$. This mixture was incubated at $37^{\circ} \mathrm{C}$ for $10 \mathrm{~min}$. FN-coated or uncoated latex beads were added to the cell culture medium in each well at a density of $5 \times 10^{6}$, to a final volume of $100 \mu \mathrm{l}$. The cells were incubated at $37^{\circ} \mathrm{C}$ for 0,1 , 3, 6 or 12 h. Following this, they were digested and dispersed with $0.25 \%$ parenzyme. The digests were washed three times with PBS to remove the non-adherent latex beads and were subsequently resuspended in PBS.

Flow cytometry (excitation wavelength, $488 \mathrm{~nm}$; emission wavelength, $530 \pm 15 \mathrm{~nm}$ ) was used to calculate the phagocytic activity of 10,000 ARPE-19 cells following treatment with latex beads. The percentage of cells containing phagocytosed

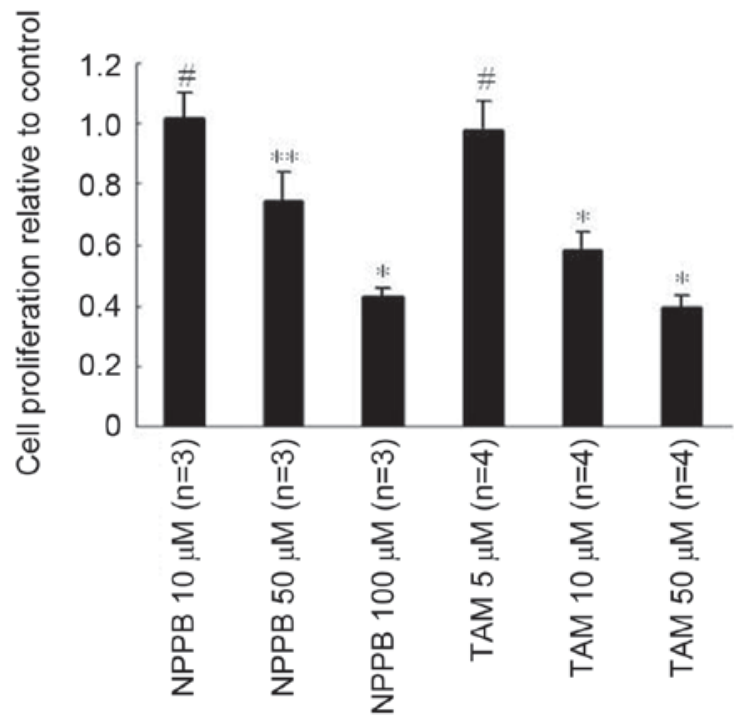

Figure 1. Effect of the chloride channel blockers NPPB and TAM on the proliferation of ARPE-19 cells. Data are presented as the mean \pm standard deviation ( $\mathrm{n}=3$, NPPB treated groups; $\mathrm{n}=4$, TAM treated groups). ${ }^{* *} \mathrm{P}<0.05$, ${ }^{*} \mathrm{P}<0.01$ and ${ }^{\#} \mathrm{P}>0.05$ vs. control. NPPB, 5-nitro-2-(3-phenylpropylamino) benzoic acid; TAM, tamoxifen.

latex beads and the amount of latex beads that were phagocytosed was defined as the phagocytic index.

Effect of ClC blockers on RPE cell phagocytosis of FN. ARPE-19 cells were treated with 10,50 or $100 \mu \mathrm{M}$ NPPB, or 5, 10 or $50 \mu \mathrm{M}$ TAM for $1 \mathrm{~h}$. These concentrations do not cause cell death (20-22). Following this, FN-coated or uncoated latex beads were added into the culture media and incubated at $37^{\circ} \mathrm{C}$ for $3 \mathrm{~h}$. The cells were subsequently digested and dispersed, and the phagocytic index was measured using flow cytometry.

Measurement of intracellular calcium concentration. Fura-2-acetoxymethyl ester (AM) was used to measure intracellular calcium $\left(\mathrm{Ca}^{2+}\right)$ levels. ARPE-19 cells were incubated with $10 \mu \mathrm{mol} / 1$ membrane-permeant Fura-2AM in hypotonic saline solution for $1 \mathrm{~h}$ in the dark at room temperature. NPPB (50 or $100 \mu \mathrm{M}$ ) or TAM (50 or $100 \mu \mathrm{M}$ ) was added to the hypotonic solutions to the final concentration (reported in the Results section) and fluorescence emission was measured using a RF-5301 PC Spectrofluorophotometer (Shimadzu Corporation, Kyoto, Japan) at a wavelength of $510 \mathrm{~nm}$ using excitation wavelengths of 340 and $380 \mathrm{~nm}$.

Statistical analysis. All experiments were repeated at least three times. Data are presented as the mean \pm standard deviation. One-way analysis of variance was used to analyze significance, and comparisons between the groups was made by analyzing data using one-way analysis of variance and the Student-Newman-Keuls method. $\mathrm{P}<0.05$ was considered to indicate a statistically significant difference.

\section{Results}

Effect of ClC blockers NPPB and TAM on ARPE-19 cell viability and proliferation. An initial screening assessment was used to determine the optimal concentrations of NPPB 

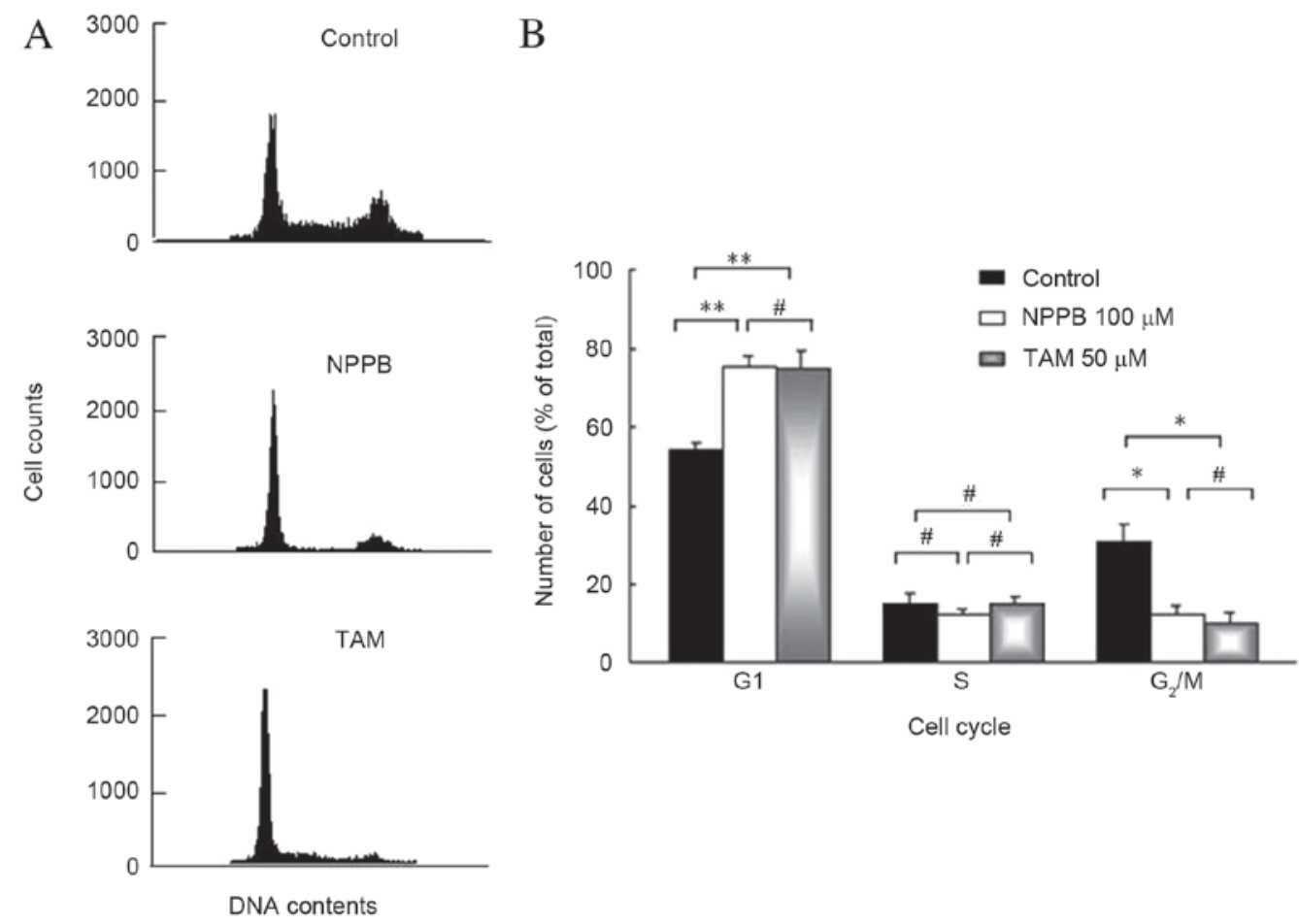

Figure 2. Effect of the chloride channel blockers NPPB and TAM on the cell cycle, as assessed by flow cytometry. (A) Flow cytometry histograms where the first peak represents cells in $G_{1}$ phase and the second peak represents cells in the $G_{2} / M$ phase. The area between the primary peaks represents cells in the $\mathrm{S}$ phase. (B) Quantification of flow cytometry. Data are presented as the mean \pm standard deviation ( $\mathrm{n}=3$, NPPB treated groups; $n=4$, TAM treated groups). ${ }^{* *} \mathrm{P}<0.05 ;{ }^{*} \mathrm{P}<0.01 ;{ }^{*} \mathrm{P}>0.05$. NPPB, 5-nitro-2-(3-phenylpropylamino)benzoic acid; TAM, tamoxifen.

and TAM that were not cytotoxic to ARPE-19 cells during a 48-h treatment period. In all groups, the cells demonstrated $>95 \%$ viability, and no significant differences were observed between the control and inhibitor groups. The effects of NPPB and TAM on the proliferation of ARPE-19 cells are presented in Fig. 1. No significant differences were observed in cell proliferation in the $10 \mu \mathrm{M} \mathrm{NPPB}$ or $5 \mu \mathrm{m}$ TAM-treated groups, compared with the control. Treatment with $50 \mu \mathrm{M}$ NPPB or $10 \mu \mathrm{M}$ TAM inhibited cell proliferation by $\sim 20$ and $40 \%$, respectively, and treatment with $100 \mu \mathrm{M}$ NPPB or $50 \mu \mathrm{M}$ TAM inhibited proliferation by $\sim 50$ or $60 \%$, respectively.

Effect of NPPB and TAM on the cell cycle. The effect of ClC blockers on the cell cycle is presented in Fig. 2. ARPE-19 cells were treated with $100 \mu \mathrm{M}$ NPPB or $50 \mu \mathrm{M}$ TAM for $48 \mathrm{~h}$. The first peak was generated by cells in the $\mathrm{G}_{1}$ phase. The second peak was generated by cells in the $\mathrm{G}_{2} / \mathrm{M}$ phase, and $\mathrm{S}$ phase cells made up the area between the two peaks. The number of cells in the $\mathrm{G}_{1}$ phase was significantly increased in cells treated with $100 \mu \mathrm{M}$ NPPB or $50 \mu \mathrm{M}$ TAM, compared with untreated cells $(P<0.05)$. The number of cells in the $\mathrm{G}_{2} / \mathrm{M}$ phase was significantly reduced in cells treated with $100 \mu \mathrm{M}$ NPPB or $50 \mu \mathrm{M}$ TAM, compared with untreated cells $(\mathrm{P}<0.05)$. No significant differences were observed in the number of cells in the $\mathrm{S}$ phase between the groups. Therefore, $\mathrm{ClC}$ blockers significantly inhibited cells from entering the DNA synthesis phase.

Phagocytosis of FN by RPE cells. The phagocytosis of FN by RPE cells is presented in Fig. 3. The first peak represents RPE cells that have not phagocytosed FN. The latter peaks represent
RPE cells that have phagoctosed FN. The phagocytic index of RPE cells increased with incubation time in a time-dependent manner, being $15 \%$ at $1 \mathrm{~h}, 35 \%$ at $3 \mathrm{~h}$ and $70 \%$ at $6 \mathrm{~h}$, peaking at $80 \%$ after $12 \mathrm{~h}$. The phagocytic index was reduced in the uncoated latex bead group, compared with the FN-coated latex bead group (data not shown).

Effects of NPPB and TAM on RPE cell phagocytosis of uncoated latex beads. The effects of NPPB and TAM on RPE cell phagocytosis of uncoated latex beads are presented in Fig. 4. The phagocytic index was $\sim 17 \%$ in the control group following a 3-h incubation with uncoated latex beads. No concentrations of NPPB or TAM had significant effects on phagocytosis of uncoated latex beads.

Effects of NPPB and TAM on RPE cell phagocytosis of $F N$-coated latex beads. The effects of NPPB and TAM on RPE phagocytosis of FN-coated latex beads are presented in Fig. 5. Compared with the control group, treatment with $10 \mu \mathrm{M}$ NPPB or $5 \mu \mathrm{M}$ TAM had no significant effect. Phagocytosis was significantly reduced in cells treated with $\geq 50 \mu \mathrm{M}$ NPPB or $\geq 10 \mu \mathrm{M}$ TAM, in a dose-dependent manner $(\mathrm{P}<0.05)$.

Effects of NPPB and TAM on $\mathrm{Ca}^{2+}$ concentration. To further investigate the underlying mechanisms of the influence of NPPB and TAM on RPE cell-directional migration prior to phagocytosis of $\mathrm{FN}$, intracellular $\mathrm{Ca}^{2+}$ levels were examined. Cells were incubated in a hypotonic environment, which induced a transient marked increase of intracellular $\mathrm{Ca}^{2+}$. Treatment with NPPB or TAM significantly reduced intracellular $\mathrm{Ca}^{2+}$ levels, in a dose-dependent manner $(\mathrm{P}<0.05$, Fig. 6). 
A

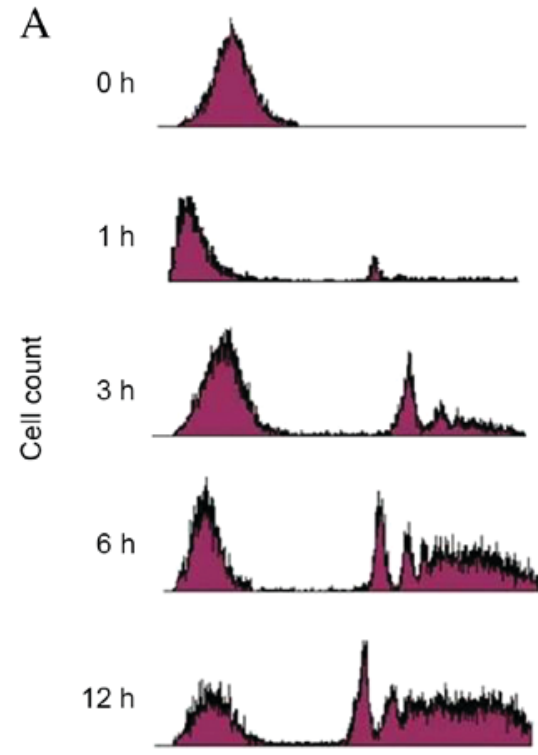

Fluorescence intensity
B

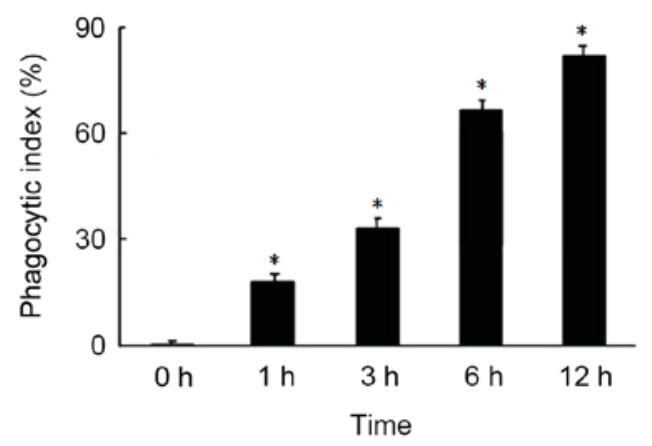

Figure 3. Phagocytosis of FN in RPE cells. (A) Flow cytometry histograms where the first peak represents the number of RPE cells that have not phagocytosed FN, and the latter peaks represent RPE cells that have phagocytosed FN. (B) Quantification of flow cytometry. The phagocytic index of RPE cells increased with incubation time in a time-dependent manner. Data are presented as the mean \pm standard deviation. ${ }^{*} \mathrm{P}<0.01$. FN, fibronectin; RPE, retinal pigment epithelial.

A
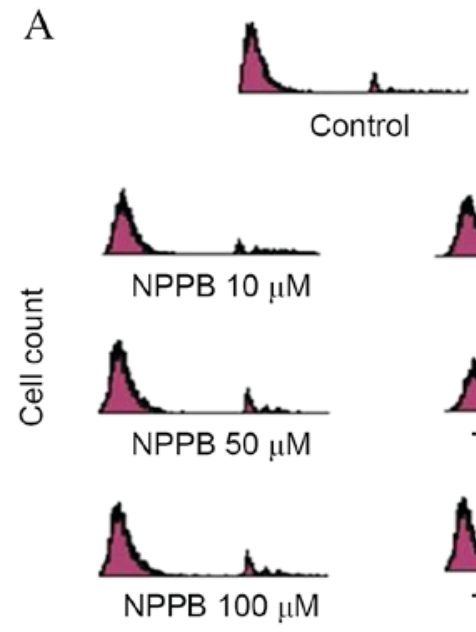

B

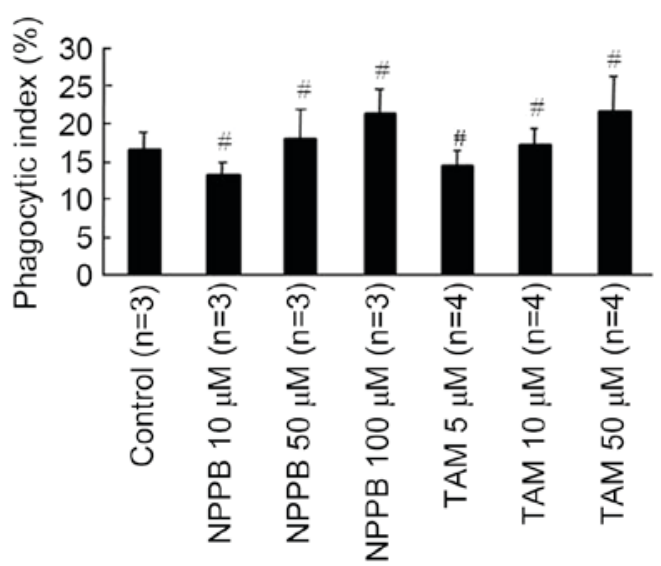

Figure 4. Effects of NPPB and TAM on RPE cell phagocytosis of uncoated latex beads. (A) Flow cytometry histograms where the first peak represents the number of RPE cells that have not phagocytosed beads, and the latter peaks represent RPE cells that have phagocytosed beads. (B) Quantification of flow cytometry. Data are presented as the mean \pm standard deviation. ${ }^{~} \mathrm{P}>0.05$ vs. control. NPPB, 5-nitro-2-(3-phenylpropylamino)benzoic acid; TAM, tamoxifen; RPE, retinal pigment epithelial.

\section{Discussion}

Abnormal proliferation and migration of RPE cells are the primary processes that mediate PVR formation. The present study demonstrated that NPPB or TAM treatment inhibited the proliferation of ARPE-19 human RPE cells in a dose-dependent manner, and blocked cells from entering $\mathrm{S}$ phase. Furthermore, the presence of FN enhanced phagocytosis. Following the development of PVR, FN predominantly enters in plasma via the damaged blood-retinal barrier, and is generated by displaced RPE cells (8). A previous study demonstrated that the composition of PVR membranes varies over time (23). The FN content of PVR membranes is significantly elevated in the first four months of PVR development (23), as in the earlier stages of wound healing, FN serves an important role in cellular adhesion. However, following scar formation, FN disappears (24). This suggests that as PVR progresses, FN may be degraded. Based on the results of the present study, this transient presence of FN may be due to RPE cells, and phagocytosis may be critical for the abnormal migration of RPE cells into the vitreous.

The results of the present study suggested that during the pathological process, retinal tears lead to a breach in the 
A

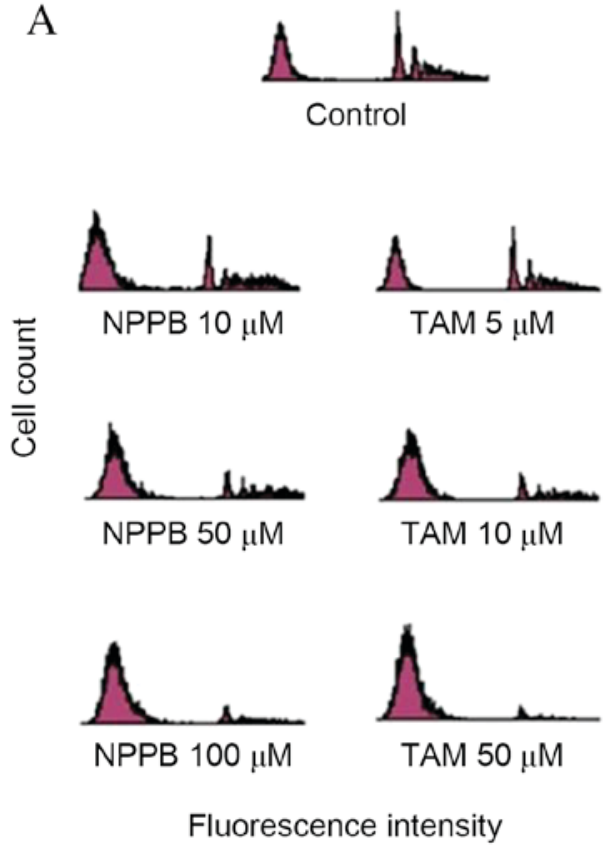

B

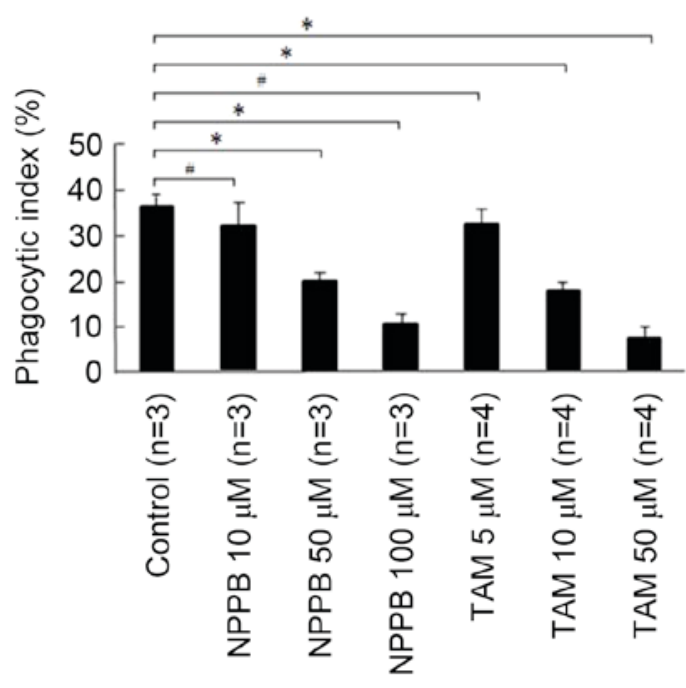

Figure 5. Effects of NPPB and TAM on RPE cell phagocytosis of FN-coated latex beads. (A) Flow cytometry histograms where the first peak represents the number of RPE cells that have not phagocytosed FN, and the latter peaks represent RPE cells that have phagocytosed FN. (B) Quantification of flow cytometry. Data are presented as the mean \pm standard deviation. ${ }^{*} \mathrm{P}<0.01,{ }^{\#} \mathrm{P}>0.05$. NPPB, 5-nitro-2-(3-phenylpropylamino)benzoic acid; TAM, tamoxifen; FN, fibronectin; RPE, retinal pigment epithelial.

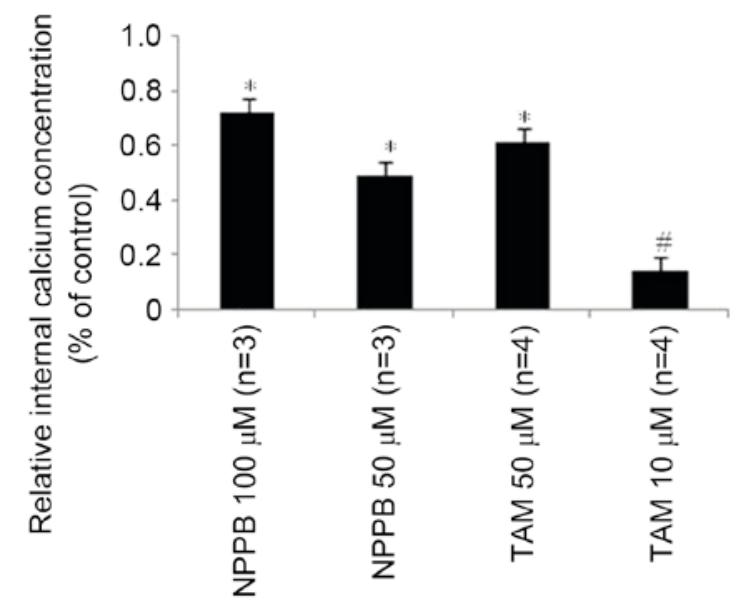

Figure 6. Relative intracellular calcium concentrations in retinal epithelial cells treated with NPPB or TAM. Cells were perfused in hypotonic solution in the presence or absence of NPPB or TAM. Data are presented as the mean \pm standard deviation $(n=3$, NPPB treated groups; $n=4$, TAM treated groups). " $\mathrm{P}<0.01$ and ${ }^{\#} \mathrm{P}>0.05$ vs. control. NPPB, 5-nitro-2-(3-phenylpropylamino)benzoic acid; TAM, tamoxifen.

blood-eye barrier. This causes the release of FN to facilitate repair of the breach. RPE cells may migrate through the retinal tear to clear the $\mathrm{FN}$; therefore, inhibiting $\mathrm{FN}$-induced RPE cell migration may have a positive effect in the prevention of PVR.

To further investigate the potential effects of ClCs on RPE cell migration, intracellular $\mathrm{Ca}^{2+}$ concentration was examined. $\mathrm{Ca}^{2+}$ is an intracellular secondary messenger, which serves a central role in signal transduction, resulting in numerous cellular responses (25). It is involved in the specific phagocytosis by RPE cells of rod outer segments, and serves an important role in cell migration (26-28). $\mathrm{Ca}^{2+}$ may facilitate loosening of cell-matrix connections (29), and the rise of intracellular $\mathrm{Ca}^{2+}$ level in the cell cytoplasm is more prominent than in the lamellipodium (30), where it may alter the structure of the cortical actomyosin gel, causing contraction (31). The present study demonstrated that the $\mathrm{ClC}$ blockers NPPB and TAM reduced intracellular $\mathrm{Ca}^{2+}$ levels, suggesting that $\mathrm{ClCs}$ may regulate intracellular $\mathrm{Ca}^{2+}$ levels in RPE cells, and subsequently contribute to the regulation of the cell migration prior to phagocytosis of FN.

These results revealed that ClCs serve important roles in human RPE cell proliferation and phagocytosis of FN, which cause RPE cell migration to the vitreous during PVR. To inhibit the formation of PVR, the molecular processes underlying RPE cell proliferation and migration have been widely investigated. A series of agents have been reported to have inhibitory effects on these processes, including mammalian target of rapamycin kinase inhibitior, protein tyrosine phosphatase $1 \mathrm{~B}$ and insulin-like growth factor binding protein-6 (32-34). Numerous signaling pathways are involved in RPE cell proliferation and migration; primarily the phosphoinositide 3-kinase/protein kinase B and mitogen activated protein kinase kinase/extracellular signal-regulated kinase-associated signaling pathways $(32,35)$. Previous studies regarding the pathogenesis of PVR have focused on the study of cytokines and proteases (36-39). The results of the present study offered novel insight into the pathogenesis of PVR by examining the nonselective ClC blockers, NPPB and TAM; however, further research is required to determine which $\mathrm{ClC}$ isoforms may be involved. In conclusion, $\mathrm{ClCs}$ may be important for the proliferation and migration of RPE cells. Targeting ClCs may provide a novel way to inhibit PVR formation. 


\section{References}

1. Ho PC and McMeel JW: Retinal detachment with proliferative vitreoretinopathy: Surgical results with scleral buckling, closed vitrectomy, and intravitreous air injection. Br J Ophthalmol 69: 584-587, 1985 .

2. Machemer R: Proliferative vitreoretinopathy (PVR): A personal account of its pathogenesis and treatment. Proctor lecture. Invest Ophthalmol Vis Sci 29: 1771-1783, 1988.

3. Rowen SL and Glaser BM: Retinal pigment epithelial cells release a chemoattractant for astrocytes. Arch Ophthalmol 103 704-707, 1985

4. Glaser BM, Cardin A and Biscoe B: Proliferative vitreoretinopathy. The mechanism of development of vitreoretinal traction Ophthalmology 94: 327-332, 1987.

5. Chan CM, Huang JH, Chiang HS, Wu WB, Lin HH, Hong JY and Hung CF: Effects of (-)-epigallocatechin gallate on RPE cell migration and adhesion. Mol Vis 16: 586-595, 2010.

6. Proctor RA: Fibronectin: A brief overview of its structure, function, and physiology. Rev Infect Dis 9 (Suppl 4): S317-S321, 1987

7. Sharma M, Tiwari A, Sharma S, Bhoria P, Gupta V, Gupta A and Luthra-Guptasarma M: Fibrotic remodeling of the extracellular matrix through a novel (engineered, dual-function) antibody reactive to a cryptic epitope on the $\mathrm{N}$-terminal $30 \mathrm{kDa}$ fragment of fibronectin. PLoS One 8: e69343, 2013.

8. Hiscott P, Waller HA, Grierson I, Butler MG and Scott D: Local production of fibronectin by ectopic human retinal cells. Cell Tissue Res 267: 185-192, 1992.

9. Nilius B and Droogmans G: Amazing chloride channels: An overview. Acta Physiol Scand 177: 119-147, 2003.

10. Zheng YJ, Furukawa T, Tajimi K and Inagaki N: Cl-channel blockers inhibit transition of quiescent (G0) fibroblasts into the cell cycle. J Cell Physiol 194: 376-383, 2003.

11. Zheng YJ, Furukawa T, Ogura T, Tajimi K and Inagaki N: M phase-specific expression and phosphorylation-dependent ubiquitination of the ClC-2 channel. J Biol Chem 277: 32268-32273, 2002.

12. Furukawa T, Ogura T, Zheng YJ, Tsuchiya H, Nakaya $H$, Katayama $\mathrm{Y}$ and Inagaki $\mathrm{N}$ : Phosphorylation and functional regulation of $\mathrm{ClC}-2$ chloride channels expressed in Xenopus oocytes by $\mathrm{M}$ cyclin-dependent protein kinase. J Physiol 540: 883-893, 2002.

13. Wills NK, Weng T, Mo L, Hellmich HL, Yu A, Wang T, Buchheit S and Godley BF: Chloride channel expression in cultured human fetal RPE cells: Response to oxidative stress. Invest Ophthalmol Vis Sci 41: 4247-4255, 2000.

14. Weng TX, Godley BF, Jin GF, Mangini NJ, Kennedy BG, Yu AS, Yu AS and Wills NK: Oxidant and antioxidant modulation of chloride channels expressed in human retinal pigment epithelium. Am J Physiol Cell Physiol 283: C839-C849, 2002.

15. Ransom CB, O'Neal JT and Sontheimer H: Volume-activated chloride currents contribute to the resting conductance and invasive migration of human glioma cells. J Neurosci 21: 7674-7683 2001.

16. Olsen ML, Schade S, Lyons SA, Amaral MD and Sontheimer H: Expression of voltage-gated chloride channels in human glioma cells. J Neurosci 23: 5572-5582, 2003.

17. Mastronardi L, Puzzilli F and Ruggeri A: Tamoxifen as a potential treatment of glioma. Anti-cancer drugs 9: 581-586, 1998.

18. Dunn KC, Aotaki-Keen AE, Putkey FR and Hjelmeland LM: ARPE-19, a human retinal pigment epithelial cell line with differentiated properties. Exp Eye Res 62: 155-169, 1996.

19. Hou Q, Tang J, Wang Z, Wang C, Chen X, Hou L, Dong XD and $\mathrm{Tu}$ L: Inhibitory effect of microRNA-34a on retinal pigment epithelial cell proliferation and migration. Invest Ophthalmol Vis Sci 54: 6481-6481, 2013.
20. Wei Y, Lin N, Zuo W, Luo H, Li Y, Liu S, Meng L, Fan A, Zhu L, Jacob TJ et al: Ethanol promotes cell migration via activation of chloride channels in nasopharyngeal carcinoma cells. Alcohol Clin Exp Res 39: 1341-1351, 2015

21. Yu Z, Zhang ZX, Li S and Gao J: Effect of a chloride channel inhibitor, 5-nitro-2-(3-phenylpropylamino)-benzoate, on ovarian cancer cell migration. Clin Lab 57: 543-550, 2011.

22. Li M, Wang B and Lin W: Cl-channel blockers inhibit cell proliferation and arrest the cell cycle of human ovarian cancer cells. Eur J Gynaecol Oncol 29: 267-271, 2008.

23. Morino I, Hiscott P, McKechnie N and Grierson I: Variation in epiretinal membrane components with clinical duration of the proliferative tissue. Br J Ophthalmol 74: 393-399, 1990.

24. Kurkinen M, Vaheri A, Roberts PJ and Stenman S: Sequential appearance of fibronectin and collagen in experimental granulation tissue. Lab Invest 43: 47-51, 1980.

25. Li M, Wang Q, Lin W and Wang B: Regulation of ovarian cancer cell adhesion and invasion by chloride channels. Int J Gynecol Cancer 19: 526-530, 2009.

26. Mergler S, Steinhausen K, Wiederholt M and Strauss O: Altered regulation of $\mathrm{L}$-type channels by protein kinase $\mathrm{C}$ and protein tyrosine kinases as a pathophysiologic effect in retinal degeneration. FASEB J 12: 1125-1134, 1998.

27. Feng W, Yasumura D, Matthes MT, LaVail MM and Vollrath D: Mertk triggers uptake of photoreceptor outer segments during phagocytosis by cultured retinal pigment epithelial cells. J Biol Chem 277: 17016-17022, 2002.

28. Wei C, Wang X, Chen M, Ouyang K, Song LS and Cheng H: Calcium flickers steer cell migration. Nature 457: 901-905, 2009.

29. Lawson MA and Maxfield FR: $\mathrm{Ca}(2+)$ - and calcineurin-dependent recycling of an integrin to the front of migrating neutrophils. Nature 377: 75-79, 1995.

30. Schwab JC, Beckers CJ and Joiner KA: The parasitophorous vacuole membrane surrounding intracellular Toxoplasma gondii functions as a molecular sieve. Proc Natl Acad Sci USA 91: 509-513, 1994.

31. Lauffenburger DA and Horwitz AF: Cell migration: A physically integrated molecular process. Cell 84: 359-369, 1996.

32. Du ZD, Hu LT, Zhao GQ, Wang Q, Xu Q, Jiang $N$ and Lin J: Protein tyrosine phosphatase $1 \mathrm{~B}$ regulates migration of ARPE-19 cells through EGFR/ERK signaling pathway. Int J Ophthalmol 8: 891-897, 2015.

33. Zhao HM, Sheng MJ and Yu J: Expression of IGFBP-6 in a proliferative vitreoretinopathy rat model and its effects on retinal pigment epithelial cell proliferation and migration. Int $\mathrm{J}$ Ophthalmol 7: 27-33, 2014.

34. Calton MA and Vollrath D: The mTOR kinase inhibitor INK128 blunts migration of cultured retinal pigment epithelial cells. Ady Exp Med Biol 854: 709-715, 2016.

35. Qin D, Zheng XX and Jiang YR: Apelin-13 induces proliferation, migration, and collagen I mRNA expression in human RPE cells via PI3K/Akt and MEK/Erk signaling pathways. Mol Vis 19: 2227-2236, 2013

36. Gao Q and Ge J: The inhibition of CA2+ influx induced by hypericin in cultured human retinal pigment epithelial cells analyzed by confocal imaging. Ophthalmic Res 37: 128-135, 2005.

37. Saika S: TGFbeta pathobiology in the eye. Lab Invest 86 : $106-115,2006$

38. Zhao MW, Jin ML, He S, Spee C, Ryan SJ and Hinton DR: A distinct integrin-mediated phagocytic pathway for extracellular matrix remodeling by RPE cells. Invest Ophthalmol Vis Sci 40: 2713-2723, 1999.

39. Tanihara $H$, Yoshida $M$, Matsumoto $M$ and Yoshimura $N$ : Identification of transforming growth factor-beta expressed in cultured human retinal pigment epithelial cells. Invest Ophthalmol Vis Sci 34: 413-419, 1993. 